\title{
Analysis of e-Advertising Influence \\ Case Study on Culinary Product
}

\author{
S Luckyardi \\ Departemen Manajemen, Universitas Komputer Indonesia \\ C N Albar \\ Departemen Sastra Inggris, Universitas Komputer Indonesia \\ N N Supriatna \\ Departemen Akuntansi, Universitas Komputer Indonesia \\ Email: timkonferensi4@gmail.com
}

\begin{abstract}
The purpose of this research is to analyse the influence of e-advertising on consumers. The case study was conducted on culinary product by performing literature study method and questionnaires. Purposive sampling technique was used with two criteria namely age and location of residence. The questionnaires was distributed among 100 respondents with age ranging from 18 to 24 years old and resided in Bandung. The results show that advertisement in social media or eadvertisements is effective to influence consumers, this is indicated by most of respondents stated that they know the product from social media, not only conventional media. In addition, the coverage of e-advertisement exposure is very extensive. This is also supported by the fact that young adults tend to use social media and other online platforms to find information regarding product. This research contribute recommendation to integrate online means in their advertisement method.
\end{abstract}

$\overline{\text { Keywords: e-advertising, product sales, social media advertising, culinary prod- }}$ uct.

Received: 22 June 2020 ;

Accepted: 18 May 2021;

Publish: December 2021

\section{How to Cite:}

Luckyardi, S, et.al. (2021). Analysis of e-Advertising Influence Case Study on Culinary Product. Journal of Business and Behavioural Entrepreneurship, 5(2), 6-12. https://doi.org/10.21009/JOBBE.005.2.02. 


\section{INTRODUCTION}

Alalwan (2017) stated that people are aware that social media influences their lives. Customers easily engage in interactions using social media such as Facebook, Instagram, Twitter, etc. Duffet said that advertising on social media could be a solution for companies that wanted to increase their sales value. By advertising, companies can achieve marketing goals. Advertising makes potential customers more familiar with the company's products and motivate the consumers to buy products (Duffett, 2015). The popularity of social media is growing rapidly as a new advertising platform, which allows users to meet and interact with brands. On the other hand, online market has a significant increase due to the growing number of online users aged 18 to 35 . The results reveal that brand awareness has an impact on users' attitudes towards social media advertising, which then influenced their behavioural responses to social media advertising and interest in buying luxury goods (Chu, et al., 2013). Marketing science stated that social media has become an important platform that is closely related to the product marketing (Lund, 2019). In this term, entrepreneurship that emphasizes business activities on technology is coined as Technopreneurship (Soegoto, 2014).

Social media is useful for knowing about competitors' movements and analyzing communication trends that are exchanged within the scope of individual consumers. It is making it easier for companies to develop solutions according to their target customers and prospects (Liu, et al., 2019). In addition, the use of advertising on social media becomes an important thing that must be done in marketing luxury branded products. This is because consumers who have an understanding of a brand have a high interest in advertising on social media and will act according to the information they get. In addition, previous studies have shown that people who understand brands will feel anxious about people's views of them if they do not use goods with these luxury brands (Chaudhry, et al., 2019).

The use of advertisements on Facebook pages and other social media show that global brands are updating their information daily. In addition, the company use social media to ask satisfaction ratings from consumers or share testimonial of their experience when using the products. This method is called electronic Word of Mouth (eWOM). e-WOM is done to maintain a good relationship with consumers (Quesenberry, et al., 2019). Electronic Word of Mouth (e-WOM) is define as the dissemination of information on a product in the form of recommendations distributed by one consumer to another consumer that can be trusted more than the company directly promotes the product. Although some of the consumers do not have many contacts to forward the message, this method should simplify the advertisers when trying to reach other consumers who are easily affected (Reichstein \& Brusch, 2001). In addition, on social media, Display ads are the most preferred advertisement for marketers. It is defined as graphic advertisements on websites appearing next to the content of web pages, instant messaging applications, e-mail messages, and other forms of communication on a website (Davis \& Cameau, 2020). However, analysis of e-advertising, specified on culinary product is still rare to be found. Therefore, this research is important to be performed. The purpose of this research is to analyse the increase in product sales using social media advertising. The research was conducted using literature study methods and questionnaires. 


\section{RESEARCH METHODS}

The method used in this research is mix method by distributing questionnaires using Google Form. Other than that, we also used literature review to support research data analysis. We took the case study on culinary product. Purposive sampling technique was used with two criteria namely age and location of residence. It was distributed among 100 respondents with age ranging from 18 to 24 years old and resided in Bandung, the respondents are decided using Slovin Formula. Young adults are chosen as the respondent because culinary businesses tend to focus their products for young adults.

\section{RESULTS AND DISCUSSIONS}

In this statement, the respondents may check more than one option. The results of the questionnaire show that 95 respondents are exposed to culinary advertisement through social media and other media such as pamphlet/brochure, video streaming platform, television and billboard. Meanwhile, 5 respondents know culinary product information not from social media. The results is in line with the previous study conducted by Saravanakumar, M., \& SuganthaLakshmi, T. (2012). They stated that companies can create a communication channel with its customers through social media. In addition it is easier tools to market their products, build brand equity, and improve consumer loyalty. Social media is a two-way channel which allows to response consumers faster. In the other hands, it requires effort and care to manage two way channel communication tools. The results of the research shown in Figure 1 also in accordance with the statement of Oktaviani, F., \& Rustandi, D. (2018) stated that the concept of digital marketing is to take advantage of a wide area of media, where the media will provide infographics about various products marketed by companies, especially the emphasis on the brand of a product or service.

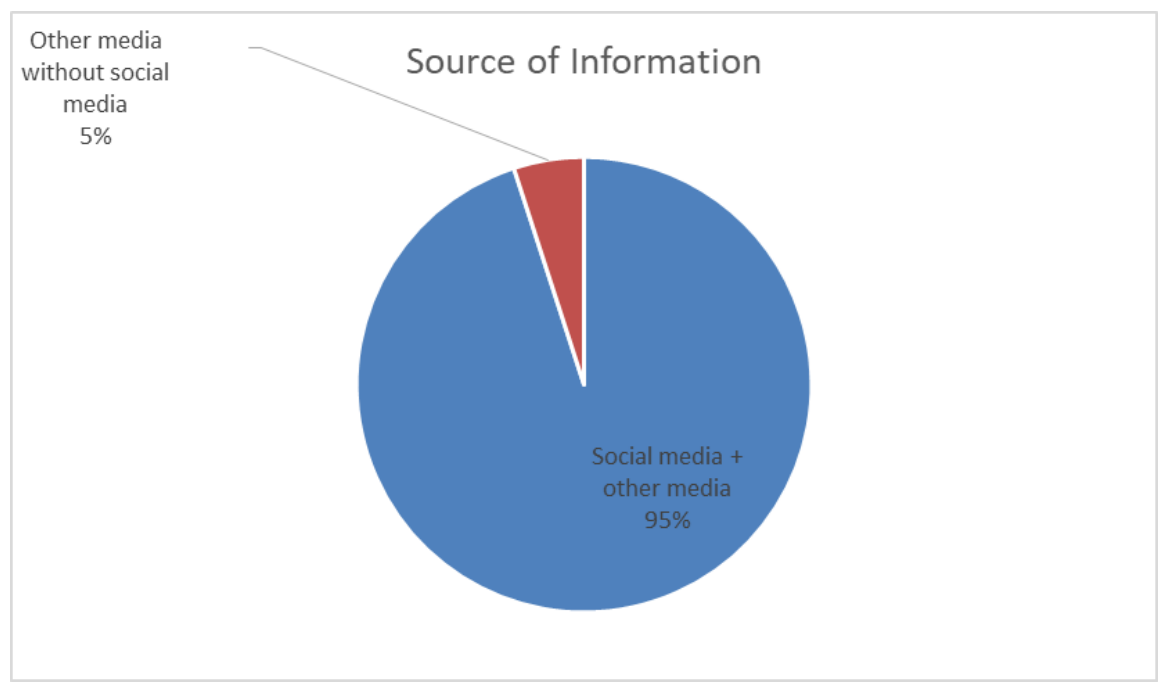

Figure 1. Source of Information

Source: Research data questionnaires

Figure 2 shown that, 64 respondents (64\%) stated that they are often exposed to culinary e-advertisement, while 33 respondents (33\%) stated that they are occasionally exposed to the ads, and 3 respondents (3\%) stated that they are rarely exposed to food advertisement. The results is supported by previous research of Andini, N. P., \& Su- 
haryono, S. (2014) stated that information on social media allows marketing to spread in a short time (wide reach), without promotional efforts and large costs.

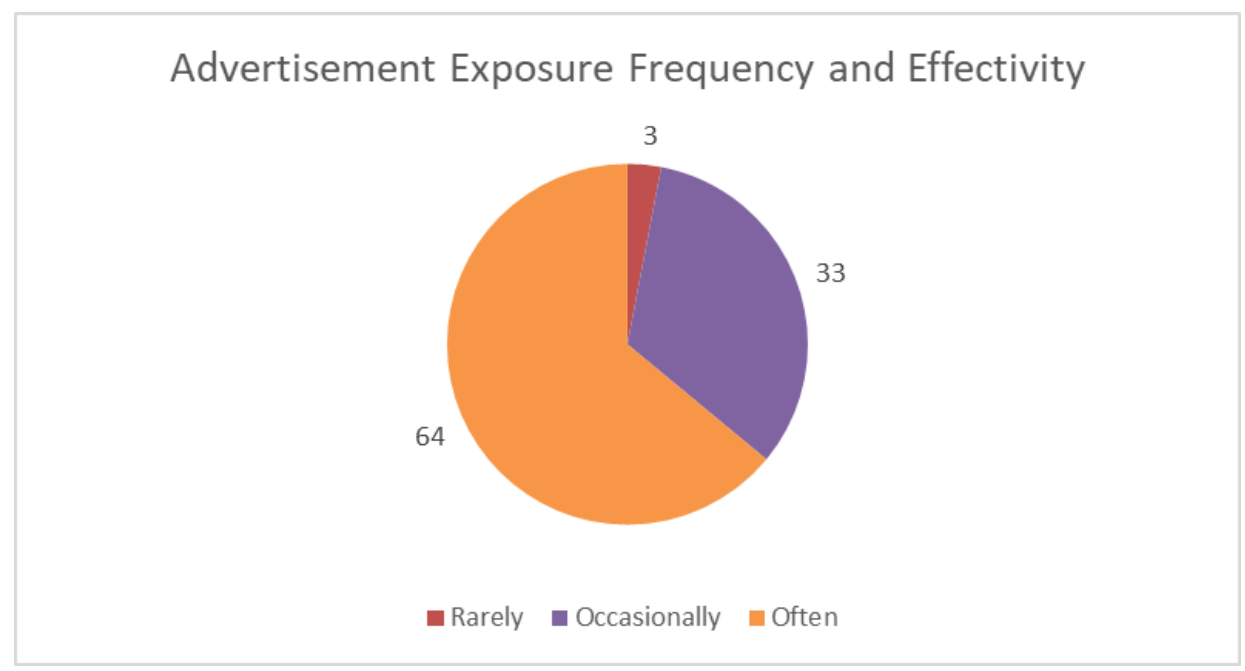

Figure 2. Advertisement Exposure Frequency and Effectivity

Source: Research data questionnaires

Figure 3 shown that text in culinary advertisement is an important aspect in advertisement. The answer of 59 respondents have proven it. The textual element in the advertisement clarify the figure in the advertisement with product information including offers, shop location, or persuasion attempt. 39 respondents $(39 \%)$ stated that both visual and textual aspects in advertisement are important (See Figure 3). According to this, customers tend to read the additional information other than figures/pictures in the advertising text. However, some consumers just do not pay attention to the textual element including the redundancy and the length of the words. This is in line with the results of previous study, which show that literal speech acts in fast food advertisements on television have various communicative functions. Textual elements can attract consumers by providing offers by involving various expressions of feelings and information about menus offered via text (Prasetya, R. A. 2017). In addition young people is a generation that has great curiosity. They tend to believe what they seeing and they analyze purchasing decision from textual and visual advertisement.

Textual element in the advertisement has a strong relation with the copywriting theory. According to advertising expert, Frank Jefkins, the definition of copywriting is a written work in the form of an advertising essay and is made as attractive and creative as possible. Person who make copywriting or creative writing is called a copywriter. Usually, copywriters make creative ideas by processing words in the form of interesting, impressive, easy to understand and persuasive writing (Agustrijanto, 2001). 


\section{The Most Important Aspect in Food Ads}

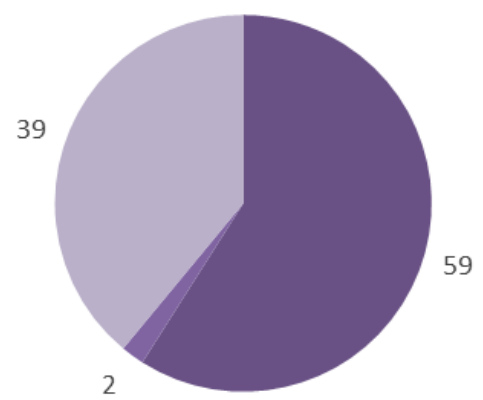

Visual of the Ads $\quad$ Text of the Ads Both Visual and Text

Figure 3. The most Important Aspect in Food Ads Source: Research data questionnaires

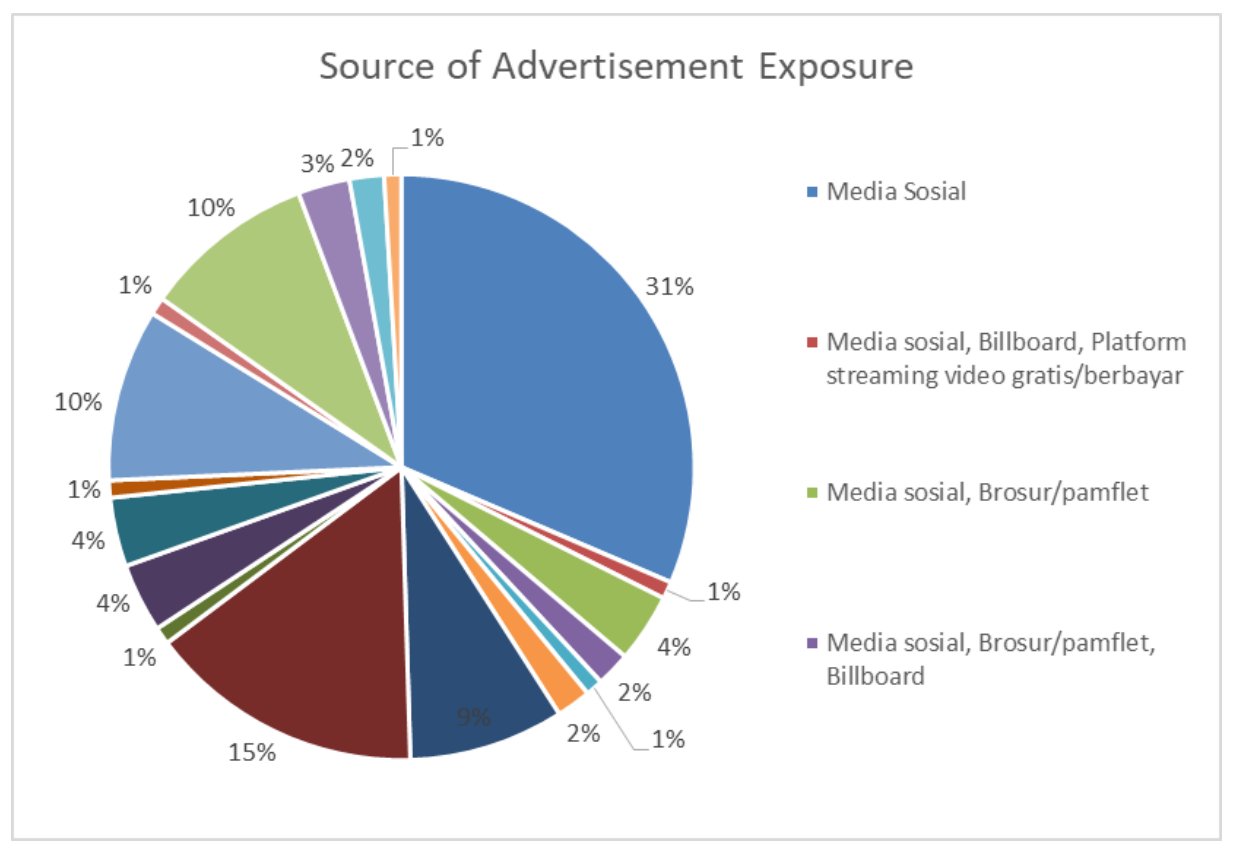

Figure 4. Source of Advertisement Exposure Source: Research data questionnaires

From Figure 4, we can find out that $31 \%$ of respondents were exposed by the advertisement in social media. By using advertisements, online businessmen or respondents can reach more targeted potential customers so they can increase sales of their products. This results is in accordance with the previous research conducted by Owen, R., \& Humphrey, P. (2009) who stated that online marketing communications creates interactions between producers and consumers rather than one direction from a producers to masses of consumers. It is enable producers to broadcast information to consumers in extensive area. 


\section{CONCLUSION}

From the results of the research above, it can be concluded that e-advertising is very effective in influencing consumers. It can be seen from the terms of source information which indicated that social media has a very broad impact on information exposure toward consumer. In addition, advertisement exposure frequency and source of advertisement exposure indicated the similar results. Exposure of the e-advertisement increase the possibility to gain consumer which in turn can gain increased profit. However, since social media is two way communication channel, it need more attention in the proper combination of textual and visual content.

\section{ACKNOWLEDGEMENT}

The author would like to thank all those involved in this research especially Prof. Ir. Dr. Eddy Soeryanto Soegoto, MT., as UNIKOM Rector and LPPM UNIKOM who support in the completion of this research.

\section{REFERENCES}

Agustrijanto. 2001. Seni Mengasah Kreatifitas dan Memahami Bahasa Iklan.Bandung: Remaja Rosdakarya.

Alalwan, A. A., Rana, N. P., Dwivedi, Y. K., \& Algharabat, R. 2017. Social media in marketing: A review and analysis of the existing literature. Telematics and Informatics, 34(7), pp.1177-1190.

Andini, N. P., \& Suharyono, S. (2014). Pengaruh Viral Marketing terhadap Kepercayaan Pelanggan dan Kepuasan Pembeli(Studi Pada Mahasiswa Fakultas Ilmu Administrasi Universitas Brawijaya 2013 yang Melakukan Pembelian Online melalui Media Sosial Instagram). Jurnal A dmistrasi Bisnis (JAB) Vol

Chaudhry, P. E., Cesareo, L., \& Pastore, A. 2019. Resolving the jeopardies of consumer demand: Revisiting demarketing concepts. Business Horizons, 62(5), pp.663 $-677$.

Chu, S. C., Kamal, S., \& Kim, Y. 2013. Understanding consumers' responses toward social media advertising and purchase intention toward luxury products. Journal of Global Fashion Marketing, 4(3), pp.158-174.

Davis, C. H., \& Comeau, J. 2020. Enterprise integration in business education: Design and outcomes of a capstone ERP-based undergraduate e-business management course. Journal of Information Systems Education, 15(3), pp. 8.

Duffett, R. G. 2015. Facebook advertising's influence on intention-to-purchase and purchase amongst Millennials. Internet Research, 25(4), pp.498-526.

Liu, Y., Jiang, C., Ding, Y., Wang, Z., Lv, X., \& Wang, J. 2019. Identifying helpful quality-related reviews from social media based on attractive quality theory. Total Quality Management \& Business Excellence, 30(15-16), pp.1596-1615.

Lund, B. 2019. Universities engaging social media users: an investigation of quantitative relationships between universities' Facebook followers/interactions and university attributes. Journal of Marketing for Higher Education, 29(2), pp.251267.

Oktaviani, F., \& Rustandi, D. (2018). Implementasi digital marketing dalam membangun brand awareness. PRofesi Humas, 3(1), 1-20.

Owen, R., \& Humphrey, P. (2009). The structure of online marketing communication channels. Journal of Management and Marketing Research, 2, 1.

Prasetya, R. A. (2017). Tindak Tutur pada Iklan Produk Makanan Cepat Saji di Televisi dan Implikasinya dalam Pembelajaran Bahasa Indonesia di Sekolah Menengah Pertama (Doctoral dissertation, UNIVERSITAS LAMPUNG). 
Quesenberry, K. A., \& Coolsen, M. K. 2019. What Makes Facebook Brand Posts Engaging? A Content Analysis of Facebook Brand Post Text That Increases Shares, Likes, and Comments to Influence Organic Viral Reach. Journal of Current Issues \& Research in Advertising, 40(3), pp.229-244.

Reichstein, T., \& Brusch, I. 2001. The decision-making process in viral marketing-A review and suggestions for further research. Psychology \& Marketing, 36(11), pp.1062-1081.

Saravanakumar, M., \& SuganthaLakshmi, T. (2012). Social media marketing. Life science journal, 9(4), 4444-4451.

Soegoto, E. S. 2014. Entrepreneurship Menjadi Pebisnis Ulung Edisi Revisi. Elex Media Komputindo. 